\title{
“Kampung Jokowi” Di Nagari: Studi Tentang Strategi Pemenangan Pemilihan Umum Rumah Kerja 01 Indonesia di Jorong Taratak Nagari Situjuah Tungka Kabupaten Limapuluh Kota
}

\author{
Silvia Rahmi Putri \\ Jurusan Ilmu Politik, Fisip, Universitas Andalas \\ E-mail: srahmi19@gmail.com
}

\begin{abstract}
Abstrak
Hal yang menarik pada pemilihan presiden Tahun 2019 dibentuknya Kampung Jokowi untuk memenangkan pasangan Jokowi dan Ma'ruf Amin. Sumatera Barat merupakan basis suara pasangan Prabowo Subianto-Sandiaga Uno juga terdapat Kampung Jokowi yakni di Jorong Taratak Nagari Situjuah Tungk. Perolehan suara di Jorong TaratakJokowi dapat berhasil unggul. Fokus dalam penelitian ini adalah strategi kemenangan yang dilakukan oleh Rumah Kerja 01 Indonesia selaku Tim sukses di daerah tersebut.Pertanyaan dari penelitian ini adalahapakah kemenangan Jokowi di "Kampung Jokowi" Jorong Taratak merupakan salah satu bentuk patronase yang dilakukan oleh Rumah Kerja 01 Indonesia.Tujuan penelitian untuk mendeskripsikan strategi para pendukung Jokowi dalam memenangkan kontestasi di "Kampung Jokowi”.Permasalahan ini kemudian di analisis menggunakan teori Patronase berfokus kepada bentuk-bentuk patronase yang dilakukan.Metode penelitian adalah kualitatif deskriptif. Hasil penelitianmenunjukan terdapat tiga dari lima bentuk patronase yang dilakukan, bentuk patronase yang ditemukan berupa pemberian barang pribadi, pemberian barang kelompok dan aktifitas dan servis. Kemenangan yang di pengaruhi oleh adanya patronase tersebut juga di dukung dengan kekuatan Muhammad Bayu Vesky sebagai presidium Rumah Kerja 01 merupakan orang asli dari Nagari Situjuah Tungka tentunya mempunyai kedekatan emosional dengan masyarakat yang berada di Nagari tersebut.
\end{abstract}

Kata kunci: Pilpres ; patronase ; kemenangan kandidat.

\begin{abstract}
The interesting thing in the 2019 presidential election was the formation of Kampung Jokowi to win over the Jokowi and Ma'ruf Amin pairs. West Sumatra is the base for the Prabowo Subianto-Sandiaga Uno pair. There is also Jokowi Village, namely in Jorong Taratak Nagari Situjuah Tungk. Jokowi's vote in Jorong Taratak was successful. The focus of this research is the winning strategy carried out by Rumah Kerja 01 Indonesia as the success team in the area. The question of this research is whether Jokowi's victory in "Kampung Jokowi" Jorong Taratak is a form of patronage carried out by Rumah Kerja 01 Indonesia. The research objective is to describe the strategy of Jokowi's supporters in winning the contestation in "Kampung Jokowi". This problem is then analyzed using Patronage theory focusing on the forms of patronage being carried out. The research method is descriptive qualitative. The results showed that there were three of the five forms of patronage that were carried out, the forms of patronage found were giving of personal items, giving group goods and activities and services. The victory which was influenced by the existence of patronage was also supported by the strength of Muhammad Bayu Vesky as the praesidium for Rumah Kerja 01, who is a native of Nagari Situjuah Tungka, of course, has emotional closeness to the people in the Nagari.
\end{abstract}

Keywords: Presidential election, patronage, candidate victory

\section{PENDAHULUAN}


Dalam sebuah kontestasi politik ada kandidat yang dapat memenangkan kontestasi politik dan ada juga gagal, strategi pemenangan yang dilakukan oleh kandidat akan menjadi hal terpenting untuk kandidat tersebut meraih suara yang sesuai dengan yang diinginkannya. Salah satu program yang dilakukan tim pasangan Jokowi dan Ma'ruf Amin adalah dengan menjadikan beberapa kampung yang ada di Indonesia dengan nama "Kampung Jokowi". Kampung Jokowi pertama kali terjadi di Kampung Pajang, Laweyan Solo. Kampung tersebut sekaligus menjadi kampung pertama yang dibentuk untuk memenangkan Jokowi-Amin dalam Pemilihan Presiden dan Wakil Presiden Tahun 2019. ${ }^{1}$ Kemudian disusul di beberapa wilayah, seperti Tanggerang Selatan, Bogor, Depok dan Belu di wilayah Provinsi Nusa Tenggara Timur (NTT) dan Kabupaten Lima Puluh Kota. Tujuan diresmikan Kampung Jokowi di beberapa daerah ini pada umumnya adalah sama yakni dikhususkan untuk memenangkan dan memberikan dukungan sepenuhnya kepada pasangan calon Presiden dan Wakil Presiden No. Urut 01 Joko Widodo Ma'ruf Amin.

Peresmian Kampung Jokowi di beberapa daerah tersebut ditargetkan sebagai peluang penyumbang suara terbesar pada Pemilihan Presiden Tahun 2019.Berbagai kegiatan yang dilakukan oleh masyarakat Kampung Jokowi untuk mengidentikkan dirinya sebagai pendukung pasangan calon tersebut. Misalnya dengan mewarnai pagar rumah mereka sesuai dengan warna partai pengusung warna merah, hitam dan putih. Kemudian melukis gambar Jokowi di lokasi tertentu serta memasang spanduk yang bertuliskan selamat datang di Kampung Jokowi. Hal lainnya yang dilakukan oleh tim pemenangan adalah memperbaiki infrastruktur yang ada di sebuah kampung, memberikan bantuan-bantuan lainnya agar masyarakat dapat tergerak hatinya untuk memilih pasangan calon dalam hal ini adalah Jokowi dan Ma'ruf Amin. Hal ini merupakan cara petahana untuk mendapatkan alokasi dana dan membawanya kepada konstituen di daerahnya dengan tujuan konstituen mendapatkan sebuah insentif agar kembali memilih petahana tersebut di periode berikutnya hal tersebut lebih dikenal dengan istilah pork barrel projects. $^{2}$

Menurut Aspinall dan Sukmajati pork barrel projects merupakan salah satu model dari patronase politik dalam pemilu. Patronase politik dalam pemilu ada lima model yaitu: Pertama adalah pembelian suara (vote buying) yang bermakna, distribusi pembayaran uang tunai/barang dari kandidat kepada pemilih. Patronase kedua dalam pemilu adalah pemberian-pemberian pribadi (individual gifts).Patronase politik ketiga dalam pemilu adalah pelayanan dan aktivitas (services and activities).Patronase politik keempat dalam pemilu adalah pemberian barangbarang kelompok (club goods).Patronase politik kelima dalam pemilu adalah proyek-proyek gentong babi (pork barrel projects), yang berarti proyek- proyek pemerintah yang ditujukan

${ }^{1}$ Lihat Tribun solo.com 2 Maret 2019, Warga Deklarasikan Kampung Jokowi-Amin Di 16 RW Pajang Solo, (online) dalam (https://solo.tribunnews.com/2019/03/02/warga-deklarasikan-kampung-jokowi-amin-di-16-rw-pajang-solo) diakses pada tanggal 20 November 2019, Pukul 21.10 WIB

${ }^{2}$ Antonius Saragintan. "Politik Pork Barrel Di Indonesia: Kasus Hibah Dan Bantuan Sosial Di Provinsi Banten Tahun 2011" Jurnal Politik, Vol. 2, No. 1, Tahun 2016 Hal.141 
untuk wilayah geografis tertentu. Karakter utama dari pork barrel project adalah kegiatan yang ditujukan kepada publik dan didanai dengan dana publik dengan harapan publik akan memberikan dukungan politik kepada kandidat tertentu. ${ }^{3}$ Proyek perbaikan jalan oleh Rumah Kerja 01 Indonesia tersebut termasuk dalam salah satu model patronase politik dalam pemilu termasuk jenis pork barrel projects.

Sumatera Barat menjadi salah satu daerah yang mayoritas pemilihnya memilih Prabowo dan Sandiaga Uno.Sumatera Barat menjadi lumbung suara pasangan Prabowo dan Sandiaga Uno dengan selisih suara yang sangat jauh.

Tabel 1

\section{Hasil Perhitungan Suara di Sumatera Barat}

\begin{tabular}{ccc}
\hline NO & NAMA PASANGAN CALON & HASIL PERHITUNGAN \\
& & SUARA \\
\hline 1. & Ir. H. Joko Widodo- KH Ma'ruf Amin & $14,09 \%$ \\
2. & Prabowo Subianto- Sandiaga Uno & $85,91 \%$ \\
\hline
\end{tabular}

Sumber: Kpu.go.id

Berdasarkan tabel di atas menunjukkan mayoritas penduduk di Sumatera Barat memilih Prabowo dan Sandiaga Uno untuk menjadi presiden dan wakil presiden dengan perolehan suara di Sumatera Barat mencapai 85,91\% yang mengalahkan Pasangan Jokowi dan Ma'ruf Amin yang hanya memperoleh $14.09 \%$ suara. Pasangan Prabowo dan Sandiaga Uno menjadi unggulan pasangan calon di Sumatera Barat.Hasil yang didapat oleh Pasangan Prabowo dan Sandiaga Uno sangat jauh selisihnya dengan pasangan petahana yaitu Joko Widodo dan Ma'ruf Amin.

Akan tetapi ada hal yang menarik yang terjadi pada pemilu 2019 khususnya di Sumatera Barat, sebelum pemilihan umum dilaksanakan muncul di Sumatera Barat yang menamakan kampungnya dengan "Kampung Jokowi" yang terletak di Jorong Taratak Nagari Situjuah Tungka Kecamatan Situjuah Limo Nagari Kabupaten Lima Puluh Kota. Sumatera Barat adalah mayoritas pendukung Prabowo dan Sandiaga Uno, seperti berita yang dikutip dari portal berita online Haluan,

"Muhammad Bayu Vesky sebagai Presidium Rumah Kerja Sumatera Barat mengatakan bahwa penamaan "Kampung Jokowi" di Jorong Taratak ini bermula dari kedatangan pengurus Srikandi Indonesia dan keluarga Presiden Jokowi dari Solo ke Jorong Taratak pada 27 Maret 2019. Setelah itu muncul kesepakatan antara tokoh masyarakat Jorong Taratak dengan Presidium Rumah Kerja untuk menjadikan Jorong Taratak sebagai “Kampung Jokowi” dan menerapkan Program Kampung Jokowi ke daerah tersebut. ${ }^{4}$

\footnotetext{
${ }^{3}$ Sidik Firmadi Dan Titin Purwaningsih. Analisis Institusionalisasi Partai Politik Pada Pemilu Legislatif Tahun 2014 (Studi Kasus DPD Partai Demokrat Provinsi Lampung)Jurnal PolitikVol. 3 No. 3 Tahun 2016. Hal 451

${ }^{4}$ Lihat Haluan.com 12 April 2019, Kampung Jokowi di Kabupaten Limapuluh Kota diresmikan, warga terharu, (online) dalam (https://www.harianhaluan.com/news/detail/73301/kampung-jokowi-di-limapuluh-kota-diresmikanwarga-terharu) diakses pada tanggal 10 Desember 2019 Pukul 21.00 WIB
} 
Jorong Taratak sendiri dijadikan "Kampung Jokowi" berawal dari keingininan Komunitas Srikandi Indonesia yang berkerjasama dengan presidium rumah kerja 01 Muhammad Bayu Vesky.Alasan Jorong Taratak dijadikan "Kampung Jokowi" karena menurutnya Jorong Taratak belum terbangun infraskturtur yang baik terbukti dengan askses jalan menuju dan di Jorong Taratak memprihantinkan dan sudah tidak layak lagi.

\section{Gambar 1}

Kampung Jokowi yang berada di Jorong Taratak Nagari Situjuah Tungka Kecamatan Situjuah Limo Nagari Kabupaten Limapuluh Kota

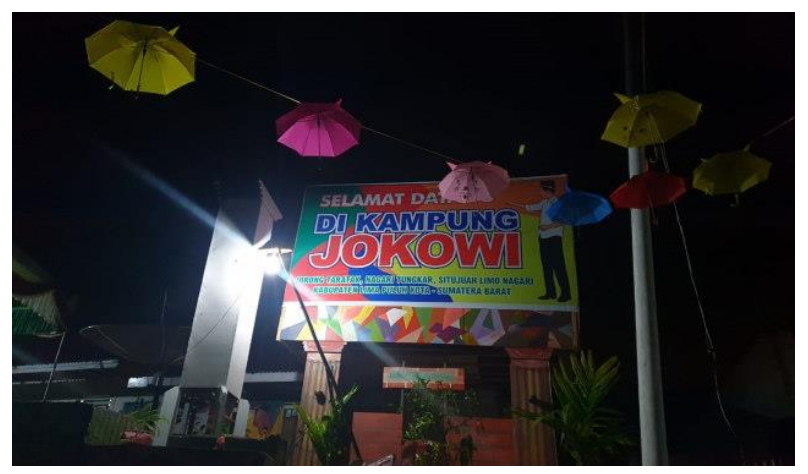

Sumber: kumparan.com

Hasil pemilihan umum di Jorong Taratak tersebut memang sangat berbeda dengan hasil yang mayoritas terjadi di Sumatera Barat.Pasangan Joko Widodo dan Ma'ruf Amin ternyata unggul mengalahkan Pasangan Prabowo dan Sandiaga Uno.

Tabel 1

Hasil Perhitungan Suara di Nagari Situjuah Tungka Kecamatan Situjuah Limo Nagari Kabupaten Limapuluh Kota

\begin{tabular}{ccc}
\hline Wilayah & Pasangan 01 & Pasangan 02 \\
\hline TPS 01 & 28 & 145 \\
TPS 02 & 19 & 128 \\
TPS 03 & 16 & 125 \\
TPS 04 & 21 & 120 \\
TPS 05 & 37 & 157 \\
TPS 06 & 31 & 153 \\
TPS 07 & 36 & 138 \\
TPS 08 & 35 & 159 \\
TPS 09 & 41 & 157 \\
TPS 10 & 37 & 139 \\
TPS 11 & $\mathbf{8 5}$ & $\mathbf{5 8}$ \\
TPS 12 & $\mathbf{8 5}$ & $\mathbf{6 0}$ \\
\hline
\end{tabular}




\begin{tabular}{ccc}
\hline TPS 13 & 36 & 128 \\
TPS 14 & 31 & 132 \\
TPS 15 & 33 & 194 \\
\hline
\end{tabular}

Sumber: Kpu.go.id

Berdasarkan hasil perhitungan suara Komisi Pemilihan Umum (KPU) yang telah selesai dilaksanakan tersebut dimana pada Jorong Taratak Pasangan Jokowi dan Ma'ruf Amin dapat unggul dari pasangan Prabowo dan Sandiaga Uno. Tabel di atas menunjukan pemilih di TPS yang ada di Nagari Situjuah Tungka dimenangkan oleh pasangan Prabowo dan Sandiaga Uno, tetapi di Jorong Taratak yang merupakan "Kampung Jokowi" yakni TPS 11 dan TPS 12 Jokowi dan Ma'ruf Amin dapat mengungguli perolehan suara dengan mendapat 85 suara. Sedangkan Prabowo dan Sandiaga Uno mendapat perolehan suara pada TPS 11 hanya 58 suara dan pada TPS 12 hanya mendapat 60 suara.

Dengan kemenangan Joko Widodo dan Ma'ruf Amin di TPS 11 dan TPS 12 adalah adanya efek dari dilakukannya bentuk-bentuk patronase politik didaerah itu. Maka rumusan masalah penelitian kali ini adalah "Apakah kemenangan Jokowi di "Kampung Jokowi" Jorong Taratak merupakan salah satu bentuk patronase yang dilakukan oleh Rumah Kerja 01 Indonesia?"

\section{Patronase}

Menurut Shefter patronase adalah sebuah pembagian keuntungan diantara politisi untuk mendistribusikan sesuatu secara individual kepada pemilih, para pekerja atau penggiat kampanye dalam rangka mendapatkan dukungan politik mereka.Patronase merupakan pemberian uang, jasa dan keuntungan ekonomi lainnya (seperti pekerjaan atau kontrak proyek) yang didistribusikan oleh politisi, termasuk keuntungan yang ditunjukan oleh individu (misal amplop berisi uang tunai) dan kepada kelompok atau komunitas (misalnya, lapangan sepak bola di sebuah kampung untuk para pemuda). Patronase juga bisa berupa uang tunai atau barang yang didistribusikan ke pemilih yang berasal dari dana pribadi (misal dalam pembelian suara) atau dari dana publik (misalnya, proyek-proyek Pork BarrelProjects yang dibiayai oleh dana pemerintah). ${ }^{5}$

Dalam patronase bukan hanya sekedar proses tukar-menukar keuntungan dalam bentuk uang, namun hubungan mutualistik lainnya yang dapat mengikat para pemilih untuk memberikan dukungan politik kepada politisi. Patronasepolitik tidak hanya memiliki sasaran pemilih secara individu saja, akan tetapi patronase politik ini juga dapat dilakukan dengan mengikat sebuah komunitas atau kelompok yang ada ditengah masyarakat.Bentuk patronase politik yangsasarannya berupa kelompok ini dapat dilakukan dengan memberikan bantuan kepada lembaga-lembaga yang ada ditengah-tengah masyarakat. Kebutuhan secara kelompok dipenuhi oleh kandidat sehingga kelompok yang ada dalam masyarakat tersebut memberikan dukungan politik kepada kandidat. ${ }^{6}$

\footnotetext{
${ }^{5}$ Aspinall, Politik Uang di Indonesia, Polgov, Jakarta, 2015, hal. 3

${ }^{6}$ Ibid, Hlm. 27
} 
Menurut Aspinall dalam buku Politik Uang di Indonesia: Patronase dan Klientelisme pada Pemilu Legislatif 2014, mengatakan bahwa ada beberapa bentuk atau variasi dari Patronase politik, diantaranya adalah;

1. Pembelian Suara (Vote Buying)

Pembelian suara merupakan distribusi pembayaran tunai atau barang dari kandidat kepada pemilih secara sistematis beberapa waktu sebelum pemilihan umum yang disertai dengan harapan implisit bahwa para penerima akan membalasnya dengan memberikan suara kepada pemberi atau kandidat. Dalam proses dristribusi uang tunai ataupun barang dari kandidat kepada pemilih. Para kandidat menggunakan tim-tim informal atau Broker yang akan menjadi perantara antara kandidat dengan para pemilih. ${ }^{7}$

2. Pemberian-Pemberian Pribadi (Individual Gift)

Pemberian-pemberian pribadi ini diartikan sebagai perekat hubungan sosial secara umum, seperti benda-benda kecil (kalender, gantugan kunci, pakaian ibadah) dan juga bahan-bahan kebutuhan pokok seperti sembako dan kebutuhan lainnya.Pemberian-pemberian pribadi ini merupakan sebuah pemberian yang dapat digunakan secara pribadi oleh para pemilih. ${ }^{8}$ Sehingga dengan pemberian secara pribadi ini para penerima terikat secara moral dengan kadidat melalui perantara pemberian tersebut.

3. Pelayanan dan Aktivitas (Services and Activities)

Pelayanan dan aktivitas ini merupakan bagaimana kandidat memberikan pelayananpalayanan yang dibutuhkan oleh masyarakat.Misalkan pemberian pelayanan kendaraan berobat gratis, atau ambulan gratis bagi masyarakat yang sedang sakit.Hal ini dilakukan agar masyarakat merasakan bahwa kandidat tersebut sangat baik kepada masyarakat. ${ }^{9}$

4. Barang-Barang Kelompok (Club Goods)

Barang-barang kelompok ini merupakan pemberian dari kandidat kepada kelompokkelompok masyarakat secara bersama dan untuk kebutuhan bersama.Kandidat memberiak bantuan kepada kelompok-kelompok ataupun komunitas yang ada ditengah masyarakat dengan harapan kelompok atau komunitas tersebut mau memberikan dukungan politiknya terhadap kendidat tersebut. ${ }^{10}$

5. Proyek-proyek gentong babi (Pork Barrel Projects)

Proyek-proyek gentong babi merupakan proyek-proyek pemerintah yang ditunjukan untuk wilayah geografis tertentu. Karakter utama dari Pork Barrel Projects ini adalah bahwa kegiatan ini ditunjukan kepada publik dan didanai dengan dana publik dengan harapan publik akan memberikan dukungan politik terhadap kandidat tertentu. Kandidat menjanjikan akan memberikan "program-program" dan "proyek-proyek" yang didanai dari dana publik untuk

\footnotetext{
${ }^{7}$ Aspinall. op.cit. hlm. 24

${ }^{8}$ Ibid Hal.25

${ }^{9}$ Ibid Hal.26

${ }^{10}$ Ibid Hal.27
} 
konsituen mereka yang biasa berupa proyek-proyek infrastruktur berskala kecil atau keuntungan kelompok tertentu, terutama untuk aktivitas-aktivitas yang bisa menghasilkan pendapatan. ${ }^{11}$

\section{METODE PENELITIAN}

Penelitian tentang "Kampung Jokowi" Di Nagari : Studi Tentang Strategi Pemenangan Pemilihan Umum Rumah Kerja 01 Indonesia Di Jorong Taratak Nagari Situjuah Tungka Kecamatan Situjuah Limo Nagari Kabupaten Limapuluh Kotamenggunakan pendekatan penelitian kualitatif, karena tujuan penelitian ini adalahmendeskripsikan strategi para pendukung Jokowi dalam memenangkan kontestasi di "Kampung Jokowi".

Penelitian kualitatif menekankan pada quality atau hal yang paling penting dari sifat suatu barang atau jasa.Tipe penelitian yang digunakan adalah tipe penelitian deskriptif, yakni data yang terkumpul berbentuk kata-kata, gambar dan bukan angka-angka. Penggunaan data berupa angka-angka hanya sebagai penunjang.

Dalam penelitian kali ini, peneliti mengambil lokasi penelitian di Jorong Taratak, Nagari Tungka Kecamatan Situjuah Limo Nagari Kabupaten Limapuluh Kota karena berdasarkan penjelasan sebelumnya di daerah tersebut diresmikan sebuah Kampung, yang diberi nama Kampung Jokowi dan setelah Pemilihan Umum berlangsung Pasangan Jokowi-Ma'ruf Amin dapat unggul di daerah tersebut.

Pada penelitian ini, peneliti memiliki peran sebagai alat untuk memperoleh data dan informasi yang dibutuhkan untuk penelitian (instrument), yang harus bersikap responsive dan mampu menyesuaikan diri dengan lingkungan.

Untuk penelitian kali ini unit analisis peneliti yang digunakan adalah kelompok.Kelompok atau organisasi yang dimaksud dalam penelitian ini adalah sekumpulan orang yang memiliki pengaruh dan terlibat dengan pendeklarasian Kampung Jokowi di Jorong Taratak, Nagari Tungka Kecamatan Situjuah Limo Nagari, Kabupaten Limapuluh Kota.

Pada penelitian ini teknik pengambilan informan menggunakan teknik purposive sampling.Yang dimaksud dengan purposive sampling adalah teknik pengambilan sampel dengan pertimbangan tertentu ${ }^{11}$ Untuk pengumpulan data pada penelitian ini menggunakan teknik wawancara dan dokumentasi. Sedangkan uji keabsahan data, peneliti menggunakan teknik triangulasi sumber data, dilakukan dengan membandingkan dan mengecek baik derajat kepercayaan suatu informasi yang diperoleh melalui waktu dan cara yang berbeda. Dalammenentukan informan triangulasi maka peneliti juga secara purposive memilih orangorang yang akan peneliti mintai informasi.

\section{HASIL DAN PEMBAHASAN}

\footnotetext{
${ }^{11}$ Ibid Hal.27
} 
Analisis data, dan temuan dapat dijelaskan dengan kronologis bentuk-bentuk patronase sesuai dengan urutannya yakni yang pertama pembelian suara, kedua pemberian pribadi, ketiga pemberian-pemberian kelompok, keempat pelayanan dan aktifitas kandidat, dan kelima proyek gentong babi dijelaskan satu persatu sebagai berikut :

1. Pembelian Suara

Secara definisi, aktifitas pembelian suara berkaitan erat dengan lingkup distribusi pembayaran uang tunai/barang dari kandidat kepada pemilih secara sistematis beberapa hari menjelang pemilihan umum.Akan tetapi yang terjadi di Jorong Taratak para pemilih tidak melakukan kontrak politik yang mewajibkanmasyarakat memilih Jokowi dalam Pemilihan Umum.

Pada saat sebelum Pemilihan Umum tersebut ada bantuan yang diberikan oleh Rumah Kerja 01 secara materil untuk memperbaiki jalan yang ada di Jorong Taratak, akan tetapi tidak ada perjanjianyang dilakukan antara Rumah Kerja 01 Indonesia dengan masyarakat Jorong Taratak untuk dapat memilih Jokowi pada Pemilihan Umum 2019.

Aspinall dalam buku Patronase Politiknya menjelaskan pembelian Suara atau vote buying merupakan distribusi pembayaran tunai atau barang dari kandidat kepada pemilih secara sistematis beberapa waktu sebelum pemilihan umum yang disertai dengan harapan implisit bahwa para penerima akan membalasnya dengan memberikan suara kepada pemberi atau kandidat. Dalam proses distribusi uang tunai ataupun barang dari kandidat kepada pemilih. Para kandidat menggunakantim-tim informal atau Broker yang akan menjadi perantara antara kandidat dengan para pemilih.

Akan tetapi pada penelitian ini, pembelian suara yang dilakukan oleh Jokowi beserta Rumah Kerja 01 Indonesia tidak terlalu tergambarkan dari teori yang ditulis oleh Aspinall yang mengatakan bahwa pembelian suara yang dilakukan dengan memberikan barang atau materil dengan harapan implisit bahwa para penerima akan membalasnya dengan memberikan suara kepada pemberi atau kandidat akan tetapi yang terjadi di Jorong Taratak tidak ada perjanjian yang dilakukan untuk memenangkan Jokowi di Jorong Taratak

2. Pemberian-pemberian pribadi (Individual Gift)

Pemberian-pemberian pribadi (Individual gift) merupakan benda atau barang yang diberikan kepada calon pemilih sebagai alat untuk merekatkan hubungan (Social Lubricant).Praktik pemberian ini di lapangan bisa terjadi ketika pasangan calon bertemu dengan pemilih, baik ketika kunjungan kerumah-rumah atau pada saat kampanye.Pemberian yang diberitahukan kepada peneliti oleh beberapa informan berupa pemberian baju kaos dan kalender.

Dalam bukunya Aspinall mengatakan bahwa pemberian-pemberian pribadi atau individual gift diartikan sebagai perekat hubungan sosial secara umum, seperti benda-benda kecil (kalender, gantugan kunci, pakaian ibadah) dan juga bahan-bahan kebutuhan pokok seperti sembako dan kebutuhan lainnya.Pemberian-pemberian pribadi ini merupakan sebuah pemberian yang dapat digunakan secara pribadi oleh para pemilih.Sehingga dengan pemberian secara 
pribadi ini para penerima terikat secara moral dengan kadidat melalui perantara pemberian tersebut.Sehingga dengan pemberian secara pribadi ini para penerima terikat secara moral dengan kadidat melalui perantara pemberian tersebut. Berdasarkan hasil wawancara peneliti dengan beberapa responden di Jorong Taratak tersebut mereka memang menyebutkan disana Tim Rumah Kerja 01 memberikan kaos dan kalender kepada masyarakat Jorong Taratak dihubungan dengan yang disampaikan Aspinall diatas kaos dan kalender hal tersebut barang barang kecil yang diberikan untuk mengikat secara moral pemilih dengan kandidat.

Dari penjelasan tersebut, pemberian barang barang pribadi yang diberikan itu merupakan salah satu faktor kenapa Jokowi dapat unggul di Jorong Taratak akibat adanya pemberian pemberian tersebut. Para pemilih mungkin saja memilih Jokowi karena pemberian pemberian barang pribadi oleh Jokowi melalui Rumah Kerja 01 Indonesia, dalam hal ini pemberiannya berupa baju kaos dan kalender yang dibagikan kepada masyarakat Jorong Taratak sebelum Pemilihan Umum tahun 2019 berlangsung.

\section{Pelayanan dan Aktivitas (Service and Activity)}

Menurut Aspinall pelayanan dan aktifitas (service and actifity) merupakan tindakan kandidat yang menyediakan atau membiayai beragam aktifitas dan pelayanan untuk pemilih.Mungkin hal yang dimaksud disini ada acara-acara atau hal hal yang dilakukan oleh Rumah Kerja 01 dengan memberi biaya agar terlaksananya acara acara yang ada di Jorong Taratak tersebut.Sebelum pemilihan umum di Jorong Taratak yang merupakan "Kampung Jokowi" setelah adanya perbaikan jalan yang dilakukan masyarakat adanya sebuah peresmian untuk jalan yang diperbaiki itu hal ini terbukti dengan salah satu portal berita yang mengeluarkan berita yakni klik.positif.Peresmian itu adalah sebagai wujud syukur atas selesainya gotong royong selama tujuh hari tujuh malam di Jorong Taratak, masyarakat bersama Rumah kerja 01 Sumbar dan Srikandi Indonesia merencanakan menggelar peresmian dan atas terlaksananya program kerja 'Kampung Jokowi pada tanggal 12 April 2019.

Tim pemenangan Jokowi di Jorong Taratak Nagari Situjuah Tungka menuturkan peresmian tersebut dibiayai oleh Tim Rumah Kerja 01.Hal itu sedikit membuktikan adanya pelayanan dan aktifitas (service andactifity) merupakan tindakan kandidat yang menyediakan atau membiayai beragam aktifitas dan pelayanan untuk pemilih.Tetapi hal tersebut tidak terlalu signifikan dilakukan karena hanya pada saat peresmian jalan baru di Jorong Taratak tersebut.

Pelayanan dan aktivitas juga merupakan suatu pelayanan yang diberikan kepada masyarakat untuk menunjang kemudahan-kemudahan kepada masyarakat dalam menjalani aktivitasnya.Penawaran jasa yang dimiliki oleh kandidat karena memiliki kelebihan materi atau jabatan dimanfaatkan untuk mendapatkan dukungan politik dari para pemilih untuk mendukung maupun untuk memilih dalam Pemilihan Umum. Untuk perjanjian pemberian jabatan yang dilakukan oleh kandidat di Jorong Taratak tersebut memang sama sekali tidak dilakukan.

4. Barang-Barang Kelompok (Club Goods) 
Bantuan barang-barang kelompok (Club Goods) yang diberikan memang tidak dapat digunakan untuk keperluan individu atau perorangan, bantuan yang diberikan adalah untuk keperluan bersama dan digunakan secara bersama-sama.Barang- barang kelompok merupakan barang-barang yang menguntungkan bagi kelompok (keuntungan kolektif) sosial tertentu ketimbang hanya bagi kebutuhan individual.Yang didapati peneliti adanya pemberian barang untuk kelompok seperti memperbaiki Mesjid, meberikan pemegang tangan dijalan menuju masjid, dan memperbaiki jalan umum.Dengan pemberian barang barang kelompok tersebut membuat kelompok masyarakat tersebut memberikan dukungan politiknya kepada Jokowi dan Ma'ruf Amin, inilah yang dinamakan denganbarang-barang kelompok (club goods) yang merupakan salah satu bentuk dari patronase politik.

Barang-barang kelompok ini menurut Aspinall merupakan pemberian dari kandidat kepada kelompok-kelompok masyarakat secara bersama dan untuk kebutuhan bersama. Kandidat memberikan bantuan kepada kelompok-kelompok ataupun komunitas yang ada ditengah masyarakat dengan harapan kelompok atau komunitas tersebut mau memberikan dukungan politiknya terhadap kendidat tersebut.

Pada kasus ini, pemberian barang barang kelompok yakni pegangan besi itu membuat sekelompok masyarakat yakni Lansia menjadi terbantu untuk berjalan menuju masjid, karena merasa sedikit lebih aman dari sebelumnnya. Bukti yang telah peneliti paparkan diatas mendukung memang salah satu bentuk patronase yakni pemberian barang-barang kelompok dipakai dalam strategi kemenangan yang dilakukan oleh Rumah Kerja 01 Indonesia di "Kampung Jokowi” Jorong Taratak Nagari Situjuah Tungka.

5. Proyek Gentong Babi (Pork Barrel Project)

Menurut Aspinall, karakter utama dari Pork Barrel Project ini adalah bahwa kegiatan ini ditunjukan kepada publik dan didanai dengan dana publik dengan harapan publik akan memberikan dukungan politik terhadap kandidat tertentu. Kandidat menjanjikan akan memberikan "program-program" dan "proyek-proyek" yang didanai dari dana publik untuk konstituen mereka yang biasa berupa proyek-proyek infrastruktur berskala kecil atau keuntungan kelompok tertentu, terutama untuk aktivitas aktivitas yang bisa menghasilkan pendapatan. Halhal yang peneliti dapatkan dilapangan bahwa dana ini bukan dari dana pemerintah melainkan dana sumbangan relawan Jokowi, dibuktikan dengan pernyataan yang disampaikan oleh S. Datuak Tamarajo selaku bendahara, bahwa pada saat dana itu dipergunakan tidak ada laporan pertanggung jawaban yang diminta kepadanya.

\section{KESIMPULAN}

Berdasarkan teori patronase politik yang peneliti rujuk dari Aspinall, terdapat lima bentuk patronase yaitu pembelian suara, pemberian barang pribadi, pemberian barang kelompok, servis dan aktifitas, dan proyek-proyek gentong babi. Dari 5 bentuk patronase yang ada dilapangan peneliti menemukan hanya ada 3 hal yang sangat dominan dipakai dalam strategi kemenangan 
Jokowi di "Kampung Jokowi" oleh Rumah Kerja 01 Indonesia yaitu Pemberian barang barang pribadi, pemberian barang barang kelompok dan aktifitas dan servis.

Hal-hal terkait pemberian barang-barang pribadi disini contohnya kalender dan baju kaus yang menyebabkan adanya harapan oleh tim sukses pemilih akan memilih Jokowi pada Pemilihan Umum tahun 2019. Barang barang kelompok yang diberikan di "Kampung Jokowi" adalah perbaikan jalan rusak di kampung itu agar akses jalan dikampung tersebut lebih memadai untuk dilewati, hal lainnya yang diberikan untuk kelompok yakni besi penyangga untuk jalan menuju masjid agar lansia tidak lagi susah jalan menuju masjid, dalam hal ini kelompok lansia sudah sangat terbantu dengan adanya pengangan tangan menuju masjid itu. Aktifitas dan servis ditemukan sebagaimana adanya peresmian jalan yang di biayai oleh Rumah Kerja 01 Indonesia tanpa adanya dana yang dikeluarkan masyarakat pada saat acara tersebut dilakukan, mulai pembayaran kerbau, dan bahan masak lainnya.

Indikator lainnya yakni pembelian suara dan proyek-proyek gentong babi tidak ditemukan hal tersebut dilakukan didaerah itu.Hal ini dijabarkan satu satu persatu yakni pertama pembelian suara, tidak ada pembelian suara yang terbukti dilakukan di daerah itu karena pada penerimaan bantuan bantuan tersebut tidak ada terjadi kontrak politik yang mengharuskan masyarakat memilih Jokowi dalam Pemilihan Umum tahun 2019.Poin lainnya yakni aktifitas dan service, setelah perbaikan jalan yang dilakukan oleh Rumah Kerja 01 tersebut, dilaksanakan peresmian jalan tersebut dengan diadakannya makan bersama yang dibiayai oleh Rumah Kerja 01 Indonesia.

Jadi dalam kemenangan pasangan Joko Widodo-Ma'ruf Amin pada pemilihan presiden Tahun 2019 di Jorong Taratak Nagari Situjuah Tungka dipengaruhi oleh tiga dari lima bentuk patronase yang dikemukakan oleh Aspinall. Ketiga bentuk patronase yang terdpat di Jorong Taratak Nagari Situjuah Tungka tersebut adalah pemberian barang-barang pribadi selanjutnya ada pemberian barang-barang kelompok dan yang terakhir terdapat aktifitas dan servis yang dilakukan oleh tim Rumah Kerja 01 di Jorong Taratak Nagari Situjuah Tungka pada saat menjelang pemililhan presiden Tahun 2019. Kemenangan yang di pengaruhi oleh adanya Patronase tersebut juga di dukung dengan kekuatan Muhammad Bayu Vesky sebagai presidium Rumah Kerja 01 yang merupakan orang asli dari Nagari Situjuah Tungka yang tentunya sudah mempunyai kedekatan seacara emosional dengan masyarakat yang berada di Nagari Situjuah Tungka.

\section{DAFTAR PUSTAKA}

Antonius Saragintan. "Politik Pork Barrel Di Indonesia: Kasus Hibah Dan Bantuan Sosial Di Provinsi Banten Tahun 2011” Jurnal Politik, Vol. 2, No. 1, Tahun 2016

Aspinall, Edward dan Sukmajati, Mada (Eds).2015. Politik Uang di Indonesia " Patronase dan Klientelisme pada Pemilu Legislatif 2014". Jakarta. Burhan Bungin, Metode Penelitian Kualitatif, Rajawali Pets, Jakarata, 2006. 
Burhanudin Muhtadi, Politik Uang Dan Dinamika Elektoral Di Indonesia: Sebuah Kajian Awal Interaksi Antara "Party-Id" Dan Patron-Klien, Vol.10, No.1 Pp.41-58, 201

K. Yin Robert, Studi Kasus (Desain Dan Metode), Pt Raja Grafindo Persada, Jakarta, 2003.

Polgov Afrizal, Metode Penelitian Kualitatif: Sebuah Upaya Mendukung Penggunaan Penelitian Kualitatif Dalam Berbagai Disiplin Ilmu, Pt Raja Garfindo Persada, Jakarta, 2014.

Rekha Adji Pramata, Patronase Dan Klientalisme Pada Pilkada Serentak Kota Kendari Tahun 2017" Jurnal Wacana Politik Vol. 2, No. 1, Tahun 2017

Sidik Firmadi Dan Titin Purwaningsih. Analisis Institusionalisasi Partai Politik Pada Pemilu Legislatif Tahun 2014 (Studi Kasus Dpd Partai Demokrat Provinsi Lampung)Jurnal PolitikVol. 3 No. 3 Tahun 2016

Sugiyono, Metode Penelitian Kuantitaif, Kualitatif Dan R\&D, Alfabeta, Bandung, 2014. 